\title{
Imperatives of Information and Communication Technology (ICT) for Second Language Learners and Teachers
}

\author{
Akinwamide, Timothy Kolade \\ University of Science and Technology, Ifaki Ekiti, Nigeria \\ Box 400, Ado Ekiti, Ekiti State, Nigeria \\ E-mail: akinwamidetim@rocketmail.com
}

Received: October 28, 2011

Accepted: November 20, 2011

Published: January 1, 2012

doi:10.5539/elt.v5n1p44

URL: http://dx.doi.org/10.5539/elt.v5n1p44

\begin{abstract}
The introduction of information and communication technology (ICT) to education creates new learning paradigms. We are dwelling in a world which technology has reduced to a global village and the breakthrough in technology is underpinning pedagogical submissions. It may become imperative therefore to have a rethinking on how to ameliorate the constraints of second language users through the applications of modern technologies. The interactions between new technology and pedagogical submissions have been found to an extent to be addressing the heterogeneous needs of second language learners and any global discovery which aims at minimizing learners' constraints is a welcome development in a rapidly changing world of technology. This paper therefore is an overview presentation of how modern technologies can be of assistance to both teachers and students of a second language setting. The rapid growth in ICT experienced by the technologically advanced nations of the world has helped them to overcome some of the barriers in teaching and learning. Applications of modern day's technologies in the field of teaching and learning can make it possible for teachers, students and others to join communities of people well beyond their immediate environment to critically review, analyze, contribute, criticize and organize issues logically and contextually having professionalism and the transformations of the entire society in view. Now, new technologies such as the reported computer enhancements with new software and networking make it much easier for educators to conquer space and time, with the motive of ameliorating constraints and academic conflicting issues. We can now bring learning to virtually any place on earth anytime for the purpose of achieving the desirable learning outcomes.
\end{abstract}

Keywords: Technology, Second-language, Academic-interactions

\section{Background}

The Problem of Teaching and Learning English as a Second Language - Nigeria Situation:

Several problems beset the teaching and learning of English as a second language in Nigeria. The teacher of English Language if he/she wants to make anything worthwhile in his teaching must identify and understand these areas of problems and so prepare himself towards achieving his goal. According to Nigeria situation, the National Policy of Education (reviewed 1977 and 1981) made us to understand the primary school as the foundational background of learning English. This foundational stage calls for competent and dedicated teacher. Gbenedio (1996) says, majority of the teachers who are expected to perform the foundation laying task do not have proper training in the methods of teaching English as a second language. It is a truism that a teacher can only function within the limits of his knowledge and skills no matter the age. Now, Akinwamide (2006) says one point to note is the fact that the global importance of the English language cannot be over-emphasized; using English has nothing to do with one's nationality, history or interest. English is an international language and every user wants to fall within the good users. It becomes germane for every second language users to take the advantage of the digital enhancement teaching and learning processes and get the best in language studies. The technologies are right there, from the Mobile Assisted Language Learning (MALL) a subset of both Mobile Learning (m-learning) and Computer-Assisted language learning which describes an approach to language learning that is enhanced through the use of a mobile device (CALL). MALL makes use of the mobile technologies, such as mobiles phones, MP3/MP4 players, PDAs and palmtop computers, to support students' language learning. This will also help students to access language learning materials, and to communicate with their teachers and peers, at anytime and anywhere with a wide coverage.

However, the process of learning English language after the first language has been acquired has not been favorable 
hence incomprehensible inputs/outputs are the major flaws of second language learners. The situation becomes more appalling when second language teachers whose limitations are observable in pronunciation are the teachers.

The learners imitate imperfect models and imperfection is on the increase. Bringing native speakers to teach the second language learners will not solve the problem because language has to do with culture. Inadequacy of relevant teaching aids makes the teaching and learning of English Language as a second language a complex experience. Absence of functional library system and language research centers do not help the situation. This conditions slow down the pace of mastery of the language by the pupils.

Pidgin English (a sub-standard English) is a language of commerce in many parts of Nigeria. Its use spreads across illiterate and learned ones. The structural pattern of Pidgin English is not at harmony with English structural pattern, therefore this gives room for interference. It is not unusual to see student's written work incorporating Pidgin English. University students use it more in their spoken conversation than the English language. This interference is there and is almost all pervading in the entire educational institutions.

Closely related to the above is the interference of the mother tongue with English language. The interference with the mother tongue is seen both at the spoken and written forms. Students substitute those phonemes that are strange to English with those found in their mother tongue.

E.g. English Phonemes

Yoruba Phonemes (one of the major languages in Nigeria)

$/ \mathrm{V} / \quad / \mathrm{f} /$

In the same manner, second language learners first think in their mother tongue and translate their thought to English language which many at times display incorrect output The problem of overcrowded classes is another major constraint of the language classroom in Nigeria. Language learning is a skill subject and it requires extensive practice for mastery. It is expected that students should engage in a lot of practices and drill to make them develop and perform in the second language. The few qualified teachers have many hours of teaching and grading of assignments, this condition has not been favorable for effective teaching and learning.

There have been moves by the Nigerian government and stakeholders to develop and improve the educational system in the country. Such efforts include the introduction of modern technological devices for use in schools from primary to tertiary level that could aid teaching and learning. Information and Communication technology (ICT) is employed as facilitator in the field of education to assist learners to learn faster and effective utilization of appropriate technologies as learning resources can lead to multifaceted benefits like self-paced learning, access to the resource without any time or geographical constraints, active learning experience for all students, academic interactions involving stakeholders and professionals. For functional education in the $21^{\text {st }}$ century, language teachers must go along with the technological world. In a world that technology has made academic interaction a reality, no professional can afford to be conservative. The concomitant effects of stagnancy may lead to system inferiority and isolation from the progressive societies. Jibowo (2005) says there ought to be an increased interest in the analysis of learners' needs at all professional levels to enhance the optimal gains of interactions internally and internationally at the level of the language teacher preparation programme. This becomes necessary if Language teachers and teaching are to be made current and functional. No educational ideology can afford to neglect the teacher factor and stand. Teachers of English must be equipped with the state-of-the-art technologies so as to be abreast of students and do fulfill their roles as educator.

\section{Interactions of Technologies with Language Teaching}

Education without boundaries continues to become more of a reality with each passing day and at the core of this reality is technology. Faster and smaller devices have evolved from the telephone to the radio, television, and most recently, the computer, cell phones, and the internet facilities. Variations on these devices have made expanding the boundaries of the traditional classroom a must for teachers and students wishing to gain an edge in this world of global academic competitions. Within the industrialized world, technology, mostly in the form of print and audio visual media, was used formerly to transmit academic content but now a novel dimension has been incorporated, this is the potential to facilitate communication and networking in the teaching and learning of language with the view to minimize constraints in Language Education.

There are four basic language skills and each skill differs from the other in orientations and acquisitions. The four basic skills are Listening skill, Speaking skill, Reading Skill and Writing skill.

\subsection{Listening Skill}

Listening skill is a very important language skill that plays an active role in the teaching and learning processes. Ige (2005) sees listening as the process of receiving, attending to and assigning meaning to aural stimuli. Listening 
involves acceptance of input into intake for output. Listening complexity arises as a result of hurriedly spoken statements. Hence, concerted efforts must be made and appropriate technology must be employed to teach and develop listening skills for all kinds of communications.

For instance, the use of radio/audio technology can be of great assistance to the teachers' effort. This has been employed by the BBC English Radio 'Radio English Direct Programme', which is an English Language teaching series for Africa. This method if well utilized will help a lot in comprehension of ideas, pronunciation of words and application of meanings to the optimal.

\subsection{Speaking Skill}

Projectors can also be employed to show speech making mechanisms. Right from the initiation of air in the lungs to the places and manner of articulation of sounds, all these can be made possible via animation on electronic projectors; especially where there is no language laboratory. As earlier pointed out, the problem of interference can be addressed by technological devices. For example, all the phonemes that are not attestable in the sound system of English language can be identified and the recorded model of an expert played in the classroom. Minimal pairs can be made possible via Electric Star Boards. Interactions here may be asynchronous or synchronous. This innovation in language learning gives rooms for feedback and peculiarities of individuals are addressed.

\subsection{Reading Skill}

Advance organizer can be employed as an effective and essential pre-reading technique for the teaching and learning of reading comprehension. It comes before the reading material thereby preparing the mind for comprehension. Advance Organizer helps in stimulating the learners' schema of a given topic and this goes a long way to enhance comprehension.

Lawal, Adebola and Adebileje (2005), highlighting the role of Advance Organizer, said it is to enhance proactive facilitation and minimize proactive inhibition. This in essence gives vent to the activation of the schemata for passage analysis and comprehension. The organizer helps a lot to bridge the gap between what the learner knows and the new things he/she needs to know based on the given passage. Organizers can be employed to teach the orthographic make-up of any given passage. This makes the terms and the keywords clear in application and enhances assimilation. Egbugara (1985) sees advance organizer as an instructional strategy like verbal ability. This is essential for students to benefit immensely from Reading Comprehension Classes. From the other side, it makes the teacher's job easy and result oriented.

For example, a given comprehension passage which is meant for reading comprehension in the class can be studied by the teacher and in the process identify the keywords. The list can be matched with the correct meanings or pictorial representations and displayed through Projector, Monitor, Electric Star Board or any of the e-screens.

Verbal organizer can also go along with pictorial organizer. Pictorial organizer incorporates graphical information with the cognitive structure creating an imaginative effect in the students. All these facilitate teaching and learning of English Language in a second language environment.

\subsection{Writing Skill}

Word Processors and the Teaching of Writing:

McGreal (1986) says Word Processors can serve as the device par-excellence for promoting the effective learning of the mechanics of good writing. Collier (1982) believes that the word processor promotes surprise, innovations and serendipitous learning. Better ways of expressing ideas emerge with the word processor. Writing in this method favors the employment of the Process Approach where writers engage in pre-writing, drafting and editing before the final draft. Students writing in a second language face a lot of difficulties as a result of writing in a different language which is foreign to their culture and comprehension. Hence, the process of writing in stages prior to the final writing gives a kind of advantage to the developing writers. With the correct application of the appropriate technology in language teaching, certain problems readily identified with African setting are automatically solved. Projectors can cover wide areas and solve the problem of over-crowded classes. Language teachers can give instructions via the net while the students can attempt assignments right from the web. Computers have auto-correction built-in devices for use of words, mechanics and grammar usage. More often than not, students encounter problems as a result of lack of the real object of study. There are some objects of study that cannot be brought to the classroom, for instance, immovable objects such as Ocean, Sun, Caterpillar/Tractor, Growing Embryo, Court in Session and Lives in the malls. The teacher can use projectors, lap-top computers, and any of the cinematographic technologies to show movies or pictures in the class. This may become necessary to avoid what Hubbard (2007) identified as a barrier to study. (lack of mass or the real object of study). Lack of real object of study makes students go blank since he/she has no contact with the object of study. Learning becomes easier when 
students can see, touch or feel what they are studying about; while the lack of the real object of study leads to frustration and incomprehension. Projectors can be used to give picture of the ocean, a court in session, the sun and other immovable or scarce objects of study.

\section{Benefits}

The quality of teaching and the efficiency of learning are evidently improved by the use of technologies and long time constraints disappear with the correct application of the right soft-ware in language learning. More so that the development and use of methodological and didactical e-learning concepts or a meaningful integration of multimedia learning modules in existing learning environments can certainly enhance the expected desirable goals. With the appropriate pedagogic preparation, certain skills can be specifically enhanced using the new technologies. Study skills and problem-solving as well as negotiating skills are advanced by communication and group learning and by the interplay within interactive learning environment. The use of a learning platform that permits both synchronous and asynchronous work - also on shared documents - and communication, for instance in forums and chats, supports this goal of skills acquisition in language education.

Now the global consensus that the $20^{\text {th }}$ century teaching model commonly referred to as the instructional paradigm is no longer adequate or appropriate pedagogy for educating students in the $21^{\text {st }}$ century Instead, it is now strongly advocated that students' education should shift to the 'Learning Paradigm', which compels educators to critically review, reappraise and re-strategize the design and delivery of their curriculum to ensure that it aligns more closely with the intensive global forces of change in the $21^{\text {st }}$ century.

\section{Implications}

The intention, or goal, of Governments as stated in the policies on education should correspond to the philosophy of interactions and application of Technologies with language learning in the multi-lingual African societies by thorough observation of the following.

- $\quad$ Export latest technologies that will enhance the applications of Technology in the language class.

- Examine the current status of mobile technologies in Africa in relation to the global use of modern technology with learning in the developed world in order to offer necessary assistance and hence bridge the widening divides.

- Expand available opportunities and programs for capacity training for Language teachers in the use of new technologies.

- $\quad$ Exhibit clear intentions to bridge the widening gaps between Africa and the developed world regarding access to latest technologies.

- Explore a systematic procedure for internationalization and globalization of education through global emphasis on application of the-state-of-the-art technologies in the language class.

- Encourage Local authorities and other stake-holders by subsidizing the cost of procurement of latest Technologies

\section{Conclusion}

Technology is gradually reshaping pedagogy and ameliorating the initial constraints in the teaching-learning process globally, therefore, with the current radical change in educational pedagogy, a well designed and orchestrated plan of action will be of necessity in laying a solid foundation for teaching and learning in a digital sensitive world (Akinwamide, 2007). The traditional method of making students passive listeners is not tenable among the present generation of students who are active, adventurous and highly impatient. The students want to be involved in what, where and how they learn. It is of no doubt that where new technologies are employed in teaching and learning, the process of teaching and learning becomes revealing, rewarding, exciting and thrilling; thus offering a balanced pedestal for self actualization and societal transformation.

\section{References}

Akinwamide, T. K. (2007). Enhancing teaching and learning of English using new technologies in second language environment. The $12^{\text {th }}$ Cambridge International Conference on Open and Distance Learning. Cambridge. U. K.

Alena, \& Y. L. Y. (2006). Teach Less Learn More; Using Online Simulations For Conceptual Learning. C.T. L. National University of Singapore. Kent Ridge Crescent, Singapore 119260.

Carlson, S. (2005). The Net-Generation in the Classroom. The Chronicle of Higher Education, 52(7), A34-A37

Collier, R. M. (1982). The Influence of Computer Based Text Editors on the Revision Strategies of In-experienced Writers. ERIC Document Reproduction Service No. ED 2H 998 
Egbugara V. O. (1985). The Effect of Verbal Ability on the Use of an Organizer in Physics in Unoh. In S. O. (ed), Literary and Reading in Nigeria, 3. Zaria, ABU Press.

Gbenedio, U. B. (1996). Teaching and Learning English as a Second Language. New Era Publications, Benin City.

Hubbard, R. (2007). Advanced Learning Tools for Educators. APS, USA.

Ige. B. (2005). Teaching Listening Skills in Language. Federal College of Education, Ogun State, Nigeria.

Jibowo A. V. (2005). Training Needs of English Language Teachers for Functional Education. OOU, Nigeria.

Lawal, A. Adebola, \& Adebileje, O. A. (2005). Language Communication and Education. Counstellation Books Ibadan.

McGreal, R. (1986). Word Processors and the Teaching of Writing. English Teaching Forum U. S. A. 